\title{
Living with the Gods in Fables of the Early Roman Empire
}

\begin{abstract}
This essay builds on work by the author on ancient cognitive religiosity and the Aesopic corpus. Focusing on fables datable to the early principate, it argues that, despite their debt to Aesop, their representations of divine-human relations are in some ways distinctive. Three fables are read closely to show the complexities of religious thinking, particularly about relations between individuals and gods, that may be embedded in apparently naive stories.
\end{abstract}

\section{Key words}

Aesop, Babrius, Phaedrus, Plutarch, fables, gods, cognitive religiosity, oligotheon, monotheism

$1 \quad$ Introduction

In a recent article, I explored evidence for popular thinking about divine-human relations in Aesopic fables, arguing that fables are an under-used resource for the study of Graeco-Roman cognitive religiosity. ${ }^{1}$ This essay pursues a similar theme in a related corpus: fables told or retold under the early principate.

Fables hold a distinctive place in Graeco-Roman culture. ${ }^{2}$ From the archaic period, if not earlier, to the end of antiquity and beyond, they were constantly retold and reinterpreted. Collected under the name of Aesop from at least the fourth century $\mathrm{BCE},{ }^{3}$ in the early principate they developed a new form, the single-authored biblion or libellus. ${ }^{4}$ They were used by philosophers, moralists, orators and educationalists to inform and entertain audiences of all kinds. They were widely believed to have risen

\footnotetext{
${ }^{1}$ Morgan 2013; cf. Morgan 2007, 5-8, Kurke 2011, 2-16, chh. 2-4.

${ }^{2}$ On the definition of fable see Morgan 2007, 57-60; the fables discussed in this paper are all so identified by their authors.

${ }^{3}$ West 1984.

${ }^{4}$ Phaedr. 1 pr. 3, Babr. 107.9-16; Babrius (107.9) says he was the first to 'open this door' (though Phaedrus is usually dated a generation earlier), and has already been imitated by contemporaries (Perry 1984,141 n. a).
} 
to these heights from society's lowest strata: to have originated with slaves and other subaltern groups and to remain especially useful to slaves, the poor, women, children, and the uneducated. ${ }^{5}$

Fables have been used by some modern scholars as a source for socioeconomic history, but scarcely at all as a source of ancient thinking about divinehuman relations. ${ }^{6}$ This is understandable, since fables incorporate few references to specific cults or rituals, are less intriguingly complex than myth, and are usually impossible to locate with any precision in time or place. ${ }^{7}$ Fables do, however, tell many stories of divine-human relationships and encounters, and incorporate numerous references to informal or private worship. Given fables' popularity and moralising agenda, it would be surprising if these references bore no relation to Greek or Roman religious thinking about the gods more widely. ${ }^{8}$

Aesopic fables present distinct challenges to historians of ancient religiosity: we cannot be sure when most of them first came into circulation; almost every collection is slightly different, and the largest surviving collections date to the later Roman Empire. ${ }^{9}$ Fables of the early principate have different strengths and weaknesses: on the one hand, we can locate them relatively closely in time, place, and likely readership; on the other, they belong more firmly than do Aesopica to the broad category 'literature', limiting their value as evidence for thinking outside socioliterary elites. ${ }^{10}$ In practice, fables of the early principate usually stay close in content to those of the Aesopic corpus, but both their conservatism and their occasional departures from tradition offer food for thought about early imperial religious thinking.

What follows will assume, for the sake of argument, what I have argued at length elsewhere: that fables in general have good claim to be taken seriously as a

\footnotetext{
${ }^{5}$ E.g. Liv. 2.32.9, Phaedr. 3 prol. 43-7, Quint. 11.19-21, Philostr. Im. 1.3, VA 5.14-16, Quint. 1.9.2. Proverbs, closely related to fables, are also understood as popular: e.g. Arist. ad Synesus Encom. calv. 22 p. 229; Dem. De eloc. 232, Quint. 5.11.21; Sen. ep. 94. 1-2, 5-6; Ps.-Diog., pr.; Ath. 10.86 457c; see Carnes 1988; Zafiropoulos 2001, 36-41. Cross-cultural comparisons suggest this belief is plausible: see Morgan 2007, 5-8.

${ }^{6}$ E.g. la Penna 1961, García 1978, Gual 1977, Cascajero 1991, Adrados 1987-91, Zafiropoulos 2001.

${ }^{7}$ Even e.g. Mikalson 1983, Veyne 1983 overlook them, as noted by Versnel 2011, 327. Conversely, scholars of fables have taken little interest in their religious aspects: see e.g. Nøjgaard 1964, 2.525-8.

${ }^{8}$ Postgate 1919 connects Phaedrus with Stoic thinking about the gods; cf. Karadagli 1981, 80, 161; Jedrkiewicz 1989, 208-12; Adrados 1987-91, 1.604-35 on connections between Aesopic fables and Cynicism, but contra see Zafiropoulos 2001, 36 .

${ }^{9}$ Morgan 2013, 4-6.

${ }^{10}$ Though Babrius appears soon after composition in sub-elite school texts (Hesseling 1893, cf. $P$. Bour. 1).
} 
wisdom genre, a site of thinking about how it is appropriate for human beings to live. Two other preliminary questions, however, are worth considering here. Can we justify treating early imperial fables as a group for the purpose of identifying patterns of thinking? $?^{11}$ And can we realistically treat them as saying anything, specifically, about divine-human relations?

Surviving fables of the early principate include the verse collections of Phaedrus (writing under Augustus and Tiberius) and Babrius (writing under the Flavians), ${ }^{12}$ together with a number of stories embedded in other works. ${ }^{13}$ The penetration of Greek literary genres and ideas in general into the Latin west by this period is too well known to need reiteration. Phaedrus describes himself ( 3 pr.) as a Greek-born freedman of Augustus and suggests by references to specific events that he lived in Rome, though where he was educated is unknown. ${ }^{14}$ Babrius was probably either a hellenised Italian or a Greek who took the name of an Italian patron; features of his verse indicate that he knew Latin and he is speculatively located in the same literary circles as Martial. His fables are dedicated to Alexander, client king of Rough Cilicia c.72-103 CE, a Judaeo-Armenian with close connections at Rome. ${ }^{15}$ Plutarch, source of the largest number of fables embedded in other texts in this period, was a Greek with close and extensive connections at Rome. These examples underline the dense inter-connectivity of the world in which early imperial fables were composed and the inter-cultural connections of the fabulists themselves. All fabulists of the early principate, moreover, emphasise their debt to Aesop, regularly introducing both collections and individual fables as Aesopic. ${ }^{16}$ Even Phaedrus, the only Latin author discussed here, who says occasionally that he is adding new stories to the Aesopic corpus and refers to a few contemporary Roman characters or events, takes his stories of gods from known Aesopic versions; nor do his gods acquire any distinctively Roman characteristics. ${ }^{17}$

\footnotetext{
${ }^{11}$ Cf. e.g. Jedrkiewicz 1989, 277-80, who assumes they are too diverse and contradictory to be treated as a corpus.

${ }^{12}$ Perry 1984, xlvii-xcvi; Morgan 2007, 326-30.

${ }^{13}$ I count 313 fables surviving from the first-second centuries CE, including Perotti's appendix to Phaedrus (paraphrased from a lost manuscript), Vita Aesopi, fables told or summarised in other texts, and those on papyrus. Babrius and Phaedrus survive in robust manuscript and papyrus traditions, testifying to their ongoing popularity (Perry 1984, 1xvi-lxxi, xcvi-c).

${ }^{14} 3.10,5.7$.

${ }^{15}$ Morgan 2007, App. 1.

${ }^{16}$ E.g. Babr. pr. 15, Phaedr. 1 pr. 1, 2 pr. 1, Plu., Mor. 155a, 806e, Lucian, Herm. 84.

${ }^{17}$ E.g. 4 pr. 11-13, 4.4 .22 (adding to Aesop), 2.5, 3 pr. 41.
} 
For all these reasons, we can plausibly treat surviving fables of the early principate as sharing a broad socio-cultural context. Like any fable group, they include some contradictory ideas about the gods (as about other topics). This, though, need not mean that we cannot analyse them synoptically, nor that they bear no relation to the way contemporaries thought. Thinking about divine-human relations is a challenge in any tradition and always generates tensions and paradoxes. If anything, the coherence of these stories' picture of the gods is more striking than its inconsistencies. All genres of popular morality, moreover, are tolerant of a degree of internal conflict, as users across place and time grapple with the complexities of existence, but they are also widely attested as having social currency, and amid their complexities, trends and patterns of thought do emerge. ${ }^{18} \mathrm{We}$ need not assume that fables cannot illuminate patterns of early imperial thinking about divine-human relations because they are not always consistent.

Is it not possible, though, that fables use the gods, as they use animals, as a device to talk about human behaviour? Fables about animals fall into two groups: those in which all the actors are animals, and those in which animals interact with humans and/or gods. In the first, we typically assume that animals stand for types of people, but even so, stories, for instance about dogs or lions, must say something about those animals as well as the human types they stand for, or the metaphor has no force. In the second, animals sometimes seem to represent types of people and sometimes themselves, but even where animals represent people, the story needs to represent something of human-animal relationships, or the metaphor again lacks force. In the same way, fables about gods and human beings, even if they are read as concerning intra-human relations, depend for their effect on drawing a picture of the gods that their readers also recognise as representing the gods. ${ }^{19}$

Fables, moreover, being usually very short, introduce their characters as briefly as possible, relying on audiences' existing understandings of them. The way fables present gods must therefore draw on the way gods are already understood. Even if we assume that fables use stories about gods purely to talk about human relationships, they must still, incidentally, tell us a good deal about their view of the

\footnotetext{
${ }^{18}$ On popular moral genres cross-culturally as generating systematic ideas, see Benedict 1934, 200, Barnsley 1972, cf. Hägg 1997.

${ }^{19} \mathrm{Cf}$. Tyler 2007 on Aesopic characters in fables as indices (which have a natural connection with their subject) rather than ciphers (which do not). Most commentators assume that all characters stand for human beings: e.g. Nøjgaard 1964, 2.284-319.
} 
gods. I doubt, however, that we need to be so sceptical. If we accept that fables have something to tell us about conceptualisations of human social relations, there is every reason to assume that they also speak to human relations with the gods. Divine-human relations were as central to Greeks' and Romans' view of the world as relations between human beings, and just as much represented and debated. Elsewhere in Greek and Latin literature we find it more surprising if divine-human relations are not represented or discussed than if they are, and there is no reason why fables should be less interested in them than other genres.

This does not rule out the possibility of reading fables of divine-human relations as stories about human relations too (and, for example, the epimythion of Babrius 119 explicitly allows readers to interpret that story of Hermes and a craftsman in human terms ${ }^{20}$ ). The possibility of parallel interpretation is suggestive in itself, emphasising the gods' anthropomorphism and encouraging readers to psychologise them in human terms. But we can also assume that fables offer a source of ideas and narratives about lived religion and divine-human relations in the early principate.

\section{Aesopica and the fabulists of the early principate}

Divine-human relations form a significant theme in early imperial fables: gods or heroes appearing, usually as principal actors, in around one story in five. ${ }^{21}$ Most of these gods belong to the Olympian pantheon or (like Hades, Persephone, Tyche/Fortuna, Prometheus or Heracles/Hercules) are closely linked with Olympians in myth. ${ }^{22}$ Strikingly, the wide range of 'foreign' or syncretic deities worshipped in the Roman empire by the first century CE is represented by just one brief mention of Cybele and two versions of a fable involving her priests. ${ }^{23}$ The divinities of fables

\footnotetext{
${ }^{20}$ Cf. Fables 34, 59; Perry 1984 thinks all three apocryphal. Other Babrian epimythia (10, 50 (both reckoned apocryphal), 127, cf. 136) frame the moral as about divine-human relations.

${ }^{21}$ Many fables without surviving Aesopic parallels probably had Aesopic versions. Fables embedded in other literature are often introduced as Aesopic (e.g. D.Chr. 12.7-8, 32.66, 33.16, Lucian., Herm. 84, Plu., Mor. 112a, 155a, 157b, 806e, Vit. Arat. 30). References to Aesopic fables throughout are to Chambry 1927.

${ }^{22}$ Tyche as daughter of Zeus: Pi., O. 12.1-2; Heracles as son of Zeus: Hes., Th. 943-4. Heracles and Athena appear together in a Babrian paraphrase, Crusius 1897 no. 145; Hercules arrives among the Olympians Phaedr. 4.12. The Titan Prometheus fights with Zeus against Cronus and aids the birth of Athena: A., Pr. 218, 252.

${ }^{23}$ Cybele (as Cybebe): Phaedr. 3.17; her priests: Babr. 141, Phaedr. 4.1, cf. Babr. 97, referring to a sacrifice to the Mother of the Gods.
} 
tend to be a small and conservative group: Greek-identified, long-established, and prominent elsewhere in myth, art, and cult.

Equally strikingly, few even of the Olympians play significant roles in fables, which are dominated above all by Zeus/Jupiter (who appears in twenty fables), followed by Hermes/Mercury (in eight, often alongside Zeus/Jupiter). ${ }^{24}$ Prometheus makes five appearances: once as a pre-Olympian creator of human beings but otherwise as a Hermes-like intermediary between Zeus/Jupiter and mortals. ${ }^{25}$ Aphrodite/Venus features in five stories, Apollo in four, Athena/Minerva three. Juno appears twice; Poseidon, Demeter, Mars, Bacchus, Persephone, Pluto, Castor and Pollux, and Iris just once each (not always as principal characters). ${ }^{26}$

Heracles/Hercules is the only hero with a significant presence, appearing as a main character in four stories. $^{27}$

Early imperial fables therefore have in common with the Aesopic corpus that they portray less the pantheon than what I have called an oligotheon, a select subgroup of the divinities most widely worshipped at the time. ${ }^{28}$ However many gods they know of, fables show human beings invoking and interacting with relatively few. ${ }^{29}$ No doubt the explanation is partly literary conservatism: imperial fables tend to

\footnotetext{
${ }^{24}$ Fables of this period which involve the gods usually stay close to Aesopic versions, where these are known, or refer explicitly to Greek forms of gods (e.g. the herm in Babr. 48 and Perotti 381 on 'Phoebus' of Delphi). We should therefore expect Greek ideas about these gods to dominate (and the emphasis on Zeus/Jupiter as sponsor of justice and judge is perhaps even more strongly Greek than Roman), but most fables draw in part on ideas common to both traditions and in part draw a picture somewhat distinctive to themselves (see below), while where rituals are described they are usually generic (sacrificing, making offerings, lighting lamps etc.).

${ }_{25}$ Babr. 66, Phaedr. 4.15, 16, Perotti 5-6, Vit. Aes. 94-5. Like Hermes, in fables, Prometheus often bungles his mission: cf. Babr. 66, Vit. Aes. 94-5 (in myth Prometheus is more mischievous and independent-minded than incompetent).

${ }^{26}$ Phaedr. 2.18, Perotti 11 (Juno), Babr. 59 (Poseidon), 34 (Demeter), 76 (Persephone and Pluto), Perotti 10 (Mars), Phaedr. 4.16 (Bacchus), Phaedr. 4.26 (Castor and Pollux), 72 (Iris).

${ }^{27}$ Babr. 15, 20, Phaedr. 4.12, Crusius 1897, no. 145; cf. Phaedr. 3.17, where he is mentioned in passing. Theseus appears once (Babr. 15); Babr. 63 features an unnamed hero.

${ }^{28}$ Nymphs (Babr. 92), and Selene (Plu., Mor. 157a-b) each occur once. Like Aesopica, early imperial fables involve other divine personifications which are not usually objects of cult, including the North Wind (Babr. 18), Blame (Babr. 59, Aristid. 28.136), War (Babr. 70), Hybris (Babr. 70), Truth (Babr. 126, Perotti 5-6), Falsehood (Perotti 5-6), Wealth (Phaedr. 4.12), Nature (Perotti 3), and Grief (Plu., Mor. 112a, see below, p...22.....).

${ }^{29}$ Phaedrus' pantheon is even narrower and more dominated than Babrius' by Zeus/Jupiter (Zeus: Babr. 56, 57, 59, 68, 72, 127, 142, cf. 57; Hermes: 48, 57, 68, 117, 119, 127; Aphrodite: 10; Athena and Poseidon: 59; Heracles: 15, 20; Prometheus: 66). In Phaedrus, Mercury appears only twice, with Jupiter, and Venus, Minerva and Hercules only once each, all in the same fable. (Jupiter: Phaedr. 1.2, 1.6, 3.17, 4.10, 4.12, 4.17, 4.19, cf. 3 pr., 4.11, 4.21, 5.8; Mercury: 1.2, 4.19; Prometheus: 4.16, Venus, Minerva, Hercules: 3.17.) Phaedrus' henatheistic tendencies have been linked with Stoicism and perhaps Cynicism (Oltramare 1926, 226-32, Adrados 1979-87, 1.635-41, 2.164-9, Morgan 2013, n. 6).
} 
follow Aesopic models (though this does not explain the Aesopic oligotheon ${ }^{30}$ ).

Insofar as the range of deities represented is a choice by early imperial writers, there is a limit to what we can say, especially about its omissions, without becoming speculative. We can, however, note that its overall shape - powerfully dominated by Zeus/Jupiter and his intermediaries, with substantial roles for gods associated with love and wisdom, and for popular lesser divinities such as Heracles/Hercules and Tyche/Fortuna to whom mortals commonly pray for help or good fortune - is unlikely to be accidental. These gods, and the areas of life with which they deal, are the ones which most concern wisdom writers.

It is also unlikely to be accidental that early imperial, like Aesopic, fables make few references to formal, especially public, rituals or places of worship. Two fables mention the Delphic oracle. ${ }^{31}$ In Babrius' Fable 2, a farmer goes to the city to consult a god in his temple about the loss of a fork. ${ }^{32}$ The action of Babrius 34 takes place after a group of country people have sacrificed a bull to Demeter, and that of Babrius 48 at a roadside herm. The vast majority of divine-mortal interactions, however, occur in private or informal contexts. Characters set up statues to gods or heroes at home; they pray to or encounter a god at home, as they go about their work, or in their dreams. ${ }^{33}$ What most interests fabulists about divine-human relations, and invites our interest, is how people interact with the gods beyond the controlled and choreographed loci of public, or even conventional private cults. ${ }^{34}$

The identities and roles of fabular gods in relation to mortals tend to be simple and monothematic. Aphrodite/Venus always appears as the patron of love, Athena/Minerva as dispenser of wisdom, Tyche/Fortuna and heroes as potential

\footnotetext{
${ }^{30}$ It suggests, however, that it is not an accident of survival. Cf. also early imperial proverb collections, which are dominated by Zeus, with Hermes and Heracles substantial presences but most other Olympians represented once or twice, if at all (Morgan 2013, n. 20). On monotheistic tendencies elsewhere in imperial religion see e.g. Chaniotis 2010, Cerutti 2010.

${ }^{31}$ Vit. Aes. 126, Perotti 8. Imperial fables are even more restricted than Aesopica, which show awareness of the Olympic games, Eleusinian Mysteries, Panathenaia, and of Delphi (Morgan 2013, $10)$.

${ }^{32}$ See below, p...17... 'Altars of the gods' also appear at Babr. 78.5. Babr. 54 involves a seer examining a liver, but the cult context is not described.

${ }^{33}$ E.g. Babr. 10, 20, 30, 49, 63, 117, 119, 126, Phaedr. 4.11, 4.26, Perotti 4: Morgan 2013, 10-11.

${ }^{34}$ Artemidorus shares this interest in informal encounters, sleeping and waking with gods (2.37), and, in dreams, in encounters with gods in statue form and in propria persona (2.35). Representations of gods in cult and myth naturally inform these stories (cf. Woolf 2013, 154): so e.g. in Babr. 69 Apollo is an archer. Artem. 2.37 acknowledges this too, observing that dreamers often see Aphrodite naked to the waist, Heracles with his lionskin and club etc.
} 
sources of help. ${ }^{35}$ Zeus/Jupiter's role is a little more complex, but still relatively restricted: he is above all the god who creates mortals and gives them their distinctive characteristics, rules them, gives them advice, and punishes wrongdoers.

The creation of the world is a recurring theme of early imperial, as of Aesopic, fables -- though it takes a simpler form in these stories than elsewhere in myth and literature. The creative power is almost always Zeus, sometimes aided by Hermes or Prometheus. ${ }^{36}$ Zeus, for instance, creates the oak trees (Babr. 142) and gives animals and human beings their powers of strength, speed, flight or speech. ${ }^{37}$ Zeus packs 'all good things' in a jar to give to human beings (Babr. 58). Jupiter, in his foresight, limits the gifts he gives to human beings to prevent their taking over the world (Perotti 3). Zeus also punishes evil-doers, maintaining order and justice in creation (Babr. 127).

It is Zeus/Jupiter to whom mortals go with requests for improvements in their lot: the frogs when they want a king; the dogs when they want a better life. ${ }^{38}$ Zeus/Jupiter also receives complaints and appeals when his creations come into conflict. ${ }^{39}$ On these occasions he sometimes gives advice familiar from other wisdom genres: life is hard; you must be clever to survive. ${ }^{40}$ When the oak trees, for example, complain that they are constantly being cut down, Babrius' Zeus points out that they have only themselves to blame, since they supply the wood for axe handles. ${ }^{41}$

On the whole, however, Zeus/Jupiter is a benign figure. Like all gods in fables, he is also shown as accessible and responsive to prayers. Fables nearly always show mortals calling on the gods with confidence and the gods as responding (if not always in quite the terms the suppliant hoped for). The story (Babr. 119) of the craftsman who offers cult to a domestic image of Hermes in the hope of making money, makes none, breaks the statue in a fit of temper only to find it full of gold, and comments sardonically that he didn't understand the kind of cult Hermes wanted, is

\footnotetext{
${ }^{35}$ E.g. Babr. 59, Phaedr. 3.17, Crusius 1897, 145 (Athena/Minerva offers wisdom); Babr. 49, Phaedr. 1.7.4-5, Perotti 3 (Tyche/Fortuna brings good luck); Perotti 8 (Apollo prophesies, though at Babr. 68 he is just a foil for Zeus and at Phaedr. 3 pr. 57 and 3.17.3 is only referred to, cf. Crusius 1897 152).

${ }^{36}$ E.g. Babr. 57, Phaedr. 4.16, cf. 4.10. In Phaedr. 3.18.1-2, uniquely, Juno gives the peacock his voice.

${ }^{37}$ Crusius 1897, 155; cf. Phaedr. 4.21.11-12.

${ }^{38}$ Phaedr. 1.2, 4.19 , cf. 1.6.

${ }^{39}$ Though less often in imperial than Aesopic fables, perhaps because Zeus's advice is often rather harsh: see below, p...12..

${ }^{40}$ Cf. Morgan 2007, 43-7, 70-73, 102-5, 147-8.

${ }^{41}$ Babr. 142, cf. Babr. 20: Heracles appears to a stranded ox driver only to tell him that the gods help those who help themselves.
} 
highly unusual in that the god never responds to the suppliant's prayers or actions at all.

If the gods tend to respond readily to mortals in fables, however, divinehuman communication can also be imperfect, and sometimes human beings develop characteristics or problems not intended by Zeus/Jupiter. This typically happens through the agency of Hermes/Mercury, Prometheus, or a hero to whom Zeus/Jupiter has entrusted some responsibility (like handing out intelligence). Prometheus accidentally creates tribads and effeminate men by getting drunk and attaching male genitalia to some females and vice versa (Phaedr. 4.16). Hermes is unintentionally responsible for the Arabs' becoming the world's greatest liars when his waggon of lies breaks down in Arabia and is plundered (Babr. 57).

Sometimes a minor divinity is not merely incompetent, but malevolent. Babrius 63 tells the story of a man who establishes a shrine to an (anonymous) hero in his courtyard and offers cult to him, wreathing the altars and 'drenching them in wine' ${ }^{42}$ Eventually, the hero appears to the man in a dream to tell him that he has misunderstood the role of heroes. It is gods that give good things: heroes give only bad. ${ }^{43}$ If the man wants bad things to happen, he should keep praying and sacrificing; if not, he should stop.

Imperial fables show traces here of an idea which I have suggested is detectable in Aesopic fables and which also occurs, greatly elaborated, in Greek and Latin philosophical and theological writings. ${ }^{44}$ The highest god or gods are benign, just, and efficient; they create and maintain the world well. Between these high gods and created beings, however, come lesser divinities, who are capable of both mistakes and malevolence, and who make human lives less predictable, less equitable, more difficult or less pleasant. Such stories are perhaps designed to explain the human perception that life is often difficult, chaotic and unfair, while preserving the principle that the god or gods who oversee it is or are ultimately just and benign.

The concept of a benign 'high god' is also one of several through which Greeks and Romans could focus on their relationship with one god while retaining the principle of multiple gods. Recent years have seen increasing scholarly interest in

\footnotetext{
${ }^{42}$ Cf. Aes. 121.

${ }^{43}$ Also the subject of a proverb, Zen. 5.60.

${ }^{44}$ E.g. Pl. Tim., Plu. Mor. 409e-38e, Galen UP 1.174.5-17 Helmreich; von Harnack 1924. Parker 1997 notes that democratic Athenian political oratory often makes similar claims, substituting politicians for minor deities.
} 
'pagan monotheism', cast in a number of forms from formal monotheism to ideas about the unity of the divine, and from elective devotion to one divinity to calling one's city's tutelary god the 'greatest' or 'highest'. ${ }^{45}$ Fables have not featured in these discussions, but the examples discussed above suggest that thinking about Zeus in fables has not just oligotheistic but monotheistic tendencies, in something like the sense characterised by Angelos Chaniotis as 'megatheism' and explored by Nicole Belayche in connection with heis theos inscriptions. ${ }^{46}$ If so, then given the sociocultural reach of fables, a tendency towards monotheistic thinking may have been even more widespread in Greek and Roman thinking than has hitherto been recognised. $^{47}$

Early imperial fables also share with Aesopica that the gods sometimes educate those who cultivate them. Several show divinities explaining to mortals why they have done something wrong, or offering advice on anything from appreciating one's gifts to the correct performance of cult. ${ }^{48}$ When, for example, the peacock complains to Juno that he has been given an ugly voice (Phaedr. 3.18.1-2), Juno explains that his beauty lies in the size and brilliance of his tail. The peacock, still dissatisfied, demands what use his beauty is if he is bested in song (9). Juno patiently explains that every creature has been given a different gift and, in order to live happily, one should practise contentment with one's gifts and not aspire to others' (10-15). ${ }^{49}$ Stories which involve a god's responding to mortal error, correcting it, or advising on how the mortal might think or behave better, imply a degree of complexity not only in mortal views of the gods but also in how mortals imagine that the gods view them. ${ }^{50}$ The idea, in particular, that the gods care about how their worshippers think and feel, as well as act, points to more layers of religious imagination in play than we might have expected from fables' compressed and apparently simple narratives. Assuming that fables express ideas in wider social circulation, these stories suggest that a greater complexity of cognitive and affective

\footnotetext{
${ }^{45}$ See e.g. Athanassiadi and Frede 1999; Mitchell and van Nuffelen 2010a, b.

${ }^{46}$ Chaniotis 2010, Belayche 2010; cf. Cerutti 2010 on 'hierarchical' paganism.

${ }^{47}$ Morgan 2013, 22-3, though cf. Zen. 1.91, 5.44 (daimones can be benefactors).

${ }^{48}$ See below, p $15 \ldots .$.

${ }^{49}$ An example of the convergence of fables with proverbs and other commonplaces: in Greek the idea that prudence consists in тò غ̇auтоû пра́ттєıv goes back at least to P1., Charm. 318b; cf. e.g. Zen. 2.96, 3.36 .

${ }^{50}$ Cf. e.g. Aes. 66, 119, 125.
} 
religiosity may have been available to practitioners of Graeco-Roman religions across a wider social spectrum than we often suppose.

It is evident that in many ways, the religious thinking of early imperial fables is very close to that of the Aesopic corpus. ${ }^{51}$ It is particularly notable, given the size of the corpora, that whatever their own religious practices or preferences, or those of their patrons, Phaedrus' and Babrius' stories about divine-human relationships show few, if any, marks of such preferences, or of what we might think of as distinctive features of first-century Greek or Roman religion. ${ }^{52}$ We might attribute this to generic inertia or traditionalism, but if popular wisdom material is taken seriously as a locus of ethical thinking, then that explanation is over-simple. We should rather assume that these fables represent a strain of thinking about divine-human relations which has wide currency across place and time, including in the early principate.

Where early imperial fables depart from Aesopic versions of the same stories, it is especially in three directions. They seem to avoid the complexity of Aesopic fables that involve gods, human beings and animals as separate orders of creation. They sometimes present the gods as more playful and/or less inclined to anger than in Aesopic versions. And their gods are even more likely than Aesop's to moralise at mortals. $^{53}$

It is generally accepted that animals in fables represent human beings. A few Aesopic fables, however, distinguish explicitly between gods, humans and animals, recalling the triadic structure of beings identified and discussed by Jean-Pierre Vernant. ${ }^{54}$ In Aesop's fable 57 (311), for example, Zeus creates animals and human beings, but having been created, man complains that he has no special gift. Zeus replies that he has the greatest gift of all, one confined to men and gods: speech. Humans here are distinguished from both animals and gods and located between them, just as a structuralist would expect. Surviving fables of the early principate,

\footnotetext{
${ }^{51}$ When they change details they rarely alter the divine-human interaction (e.g. Babr. 6, 24, 59, 66, 72, Phaedr. 1.6, 4.10). Imperial fables which do not appear in the Aesopic corpus but share its preoccupations include Babr. 30,136, Phaedr. 3.18, 4.15, 4.16, 4.17, P. Oxy. 1011. 160ff.; cf. Perry 1984, App. 444, 429, 433.

${ }^{52}$ E.g. imperial cult, the worship of gods favoured by emperors, worship of new divine qualities, or newly popular elective cults. This is unlikely to be accidental, given that both authors do add contemporary Roman (and historical Greek) elements: e.g. Phaedr. 2.5 concerns the emperor Tiberius; 3.pr. 41 refers to Sejanus, 3.10.34-50 to the centumviral court under Augustus; cf. Phaedr. 2.9, 4.7.21, 4.pr.10, ep.4-7, Babr. prr. to parts 1 and 2.

${ }^{53}$ In several Aesopic fables mortals get away with behaviour (such as cheating on the fulfilment of a vow) that one might expect to see punished (Morgan 2013, 23-4); imperial fables tend to avoid this theme.

${ }^{54}$ Even possibly a tetradic one: Morgan 2013, 7.
} 
however, do not include individual stories, at least, which suggest that humans and animals are distinct orders of creation. They prefer the relative simplicity of treating creation as dyadic and animals as representative of human beings.

Several Aesopic fables, in which gods are said to be angry with people, give them a comfortless answer to a plea, or punish them unmercifully for making some complaint, are omitted by both Babrius and Phaedrus and appear nowhere else in imperial literature. ${ }^{55}$ The Aesopic story, for example, of Zeus and the fox (119), in which Zeus, impressed by the fox's intelligence, makes him the king of the animals, only to reduce him to nonentity when the fox does not behave appropriately, is apparently too harsh for imperial fabulists' tastes. ${ }^{56}$ Instead we find in Phaedrus, as we have seen (3.18), that when the peacock complains to Juno about his voice he is not punished but reassured that his gift from the gods is his beauty. Also according to Phaedrus (4.17), when male goats complain to Jupiter that their wives have beards which they lack, Jupiter reassures them that, as long as they are the more courageous sex, they can afford not to worry about their appearance.

Phaedrus does even more than Babrius to soften Jupiter's interactions with his creation. The nearest he comes to the summary way in which Aesop's Zeus deals with complaints is in Fable 4.19, in which the dogs decide to petition Jupiter for a better lot in life. The first ambassadors they send are distracted on the way by looking for food, and when brought into Jupiter's presence are so awestruck that they void their bowels (10-11). On Jupiter's orders, they are not punished but simply sent away (12-13). The dogs then send another embassy, whose members try to ingratiate themselves by stuffing their rears with perfume (18-19). In Jupiter's presence, however, they too void the perfume and everything else (22-5). The other gods demand that this insult be punished (26). Jupiter (27-34) declines to punish them but he does decree that henceforth dogs will always be hungry and never be able to control their bowels. The most striking aspect of this fable, in comparison with Aesopic stories of embassies to Zeus, is not the dogs' eventual (relatively mild) punishment, but Jupiter's patience and moderation in the face of their misbehaviour. ${ }^{57}$

Even fables that stay close to Aesop often soften or lighten divine responses to mortal misbehaviour. In Aesop's fable of the house ferret whom Aphrodite changes,

\footnotetext{
${ }^{55}$ E.g. Aes. 66, 119, 125, 146, 234, 262, 291; cf. Morgan 2013a, 8-9.

${ }^{56}$ So are e.g. Aes. 146, 234, 291.

${ }^{57}$ Attributed by some to Stoic influence, but see Morgan 2007, 337-9.
} 
at her request, into a woman so that she can marry her master, the goddess deliberately tests how far the ferret has changed inside by introducing a mouse into her bridal chamber. When the woman cannot resist leaping up to chase it, Aphrodite

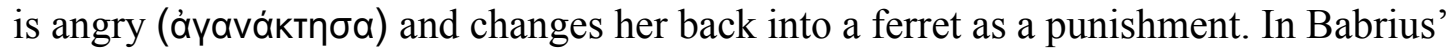
version, the appearance of the mouse (in the dining room rather than the bedchamber, perhaps a nod to Babrius' Roman context) is a coincidence rather than a test. When the woman jumps up to chase it, Babrius says,

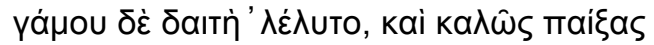

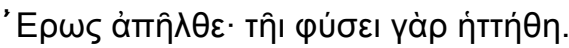

That was the end of the wedding feast, and having played nicely, Eros left: nature had beaten him. (32.9-10)

At the beginning of the story, it was Cypris who turned the ferret into a woman, but at the end Babrius substitutes the less formidable, more playful figure of Eros, who treats the whole incident as a game, and the seriousness - and sharp point - of the Aesopic version are deftly defused.

Relationships between the gods themselves also tend to be presented more lightheartedly in imperial fables than in Aesopica. Aesop 121, for example, tells how Apollo challenged Zeus to an archery contest. Zeus accepted; Apollo shot; Zeus then demonstrated his superiority by covering all the ground covered by Apollo's arrow in a single stride. Babrius, however, tells us that Zeus joins in the contest for fun (таi $\zeta \omega v$ ), and after taking his giant stride says to Apollo, 'Where shall I shoot, son? I

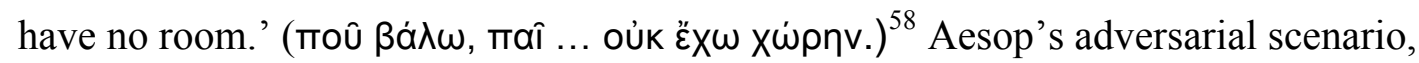
with its hints of hybris and punishment, is turned into something closer to a family game. Perotti's appendix to Phaedrus (11) offers a similarly lighthearted story of a joke made by Venus at the expense of Hera. Rather than being angry, Phaedrus concludes, Juno laughs at the joke. (11. 13-14). ${ }^{59}$

It is tempting to assume that this lightheartedness signals that Babrius and Phaedrus, at least, intend their stories to be read more as entertainment than wisdom.

\footnotetext{
${ }^{58}$ Cf. Aes $124=$ Babr. 59: in the Aesopic version Zeus is angry with Momus; in Babrius, he tolerates him.

${ }^{59}$ Cf. Perotti 4, 5-6.
} 
Phaedrus may seem to offer some support for this view, when he says that if anyone is offended by his book, fictis iocari nos meminerit fabulis, 'he should remember that I write jokingly in made-up stories' (1 pr. 7). Babrius, meanwhile, introduces his collection:

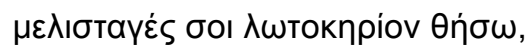

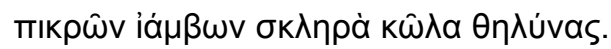

I will set before you a dripping honeycomb, softening the harsh chords of bitter iambics. (pr. 18-19, cf. 107.15-16) ${ }^{60}$

Neither Babrius nor Phaedrus, however, gives up the claim to be writing what Phaedrus calls 'wise counsels' for guiding readers through life (Phaedr. 1 pr. 4, cf. Babr. pr. 14). Moreover, though the punchy effect of Aesopic stories is often mitigated in both authors by more elaborate scene setting and sometimes by longer exchanges between characters, it is, in fact, extremely rare for either to soften the endings or morals of stories except in fables about the gods.

The softening that occurs in these stories is of a distinctive kind. There seems no obvious reason to link it to the authors' literary pretensions, since contemporary literature presents the gods in very various ways. We may also note that other forms of popular wisdom in this period, such as proverbs and gnomai, also tend to present the gods (above all, Zeus/Jupiter) as relatively kindly and reliable. ${ }^{61}$ We must, I think, take seriously the possibility there is some desire in wisdom literature of the early principate to present divine-human relations as more reliable and more consistently benign than in the past they have been understood to be.

Several early imperial fables elaborate on the tendency of Aesopic deities to moralise at created beings. ${ }^{62}$ Babrius' Fable 10 retells the story of the slave girl and Aphrodite. A man falls in love with an ugly and ill-tempered slave girl, who is convinced that she has Aphrodite to thank for her good fortune. She takes to

\footnotetext{
${ }^{60}$ Transl. Perry, modified. Perry 1984, 4-5 argues that this is about content rather than metre; it could refer to both.

${ }^{61}$ See e.g. Zenob. (2.44, 3.41, 3.98 (Zeus as benefactor), 4.11 (Zeus as just), 4.40 (the gods as counsellors)), ps.-Diogenian. (2.84, 3.15 (the gods as helpful and generous) 3.20 (the gods as just, though cf. 4.21)), Max. Tyr. 41.4, Plu., Mor. 68e, 153a, 473b, 550c, 551c (Zeus/the gods as good or just), Morgan 2007, 31-5, 111-16, 131-5, 207-11.

${ }^{62}$ Cf. e.g. Aes. $66=$ Phaedr. 1.2.
} 
worshipping the goddess regularly, asking to be made beautiful, until the goddess appears in a dream to tell her to stop. In Aesop's version (Fable 18), Aphrodite says 'I don't want to make you beautiful because I am angry with the man for thinking you are.' Babrius' Aphrodite puts it a little differently:

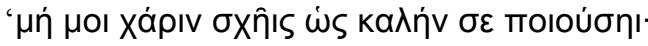

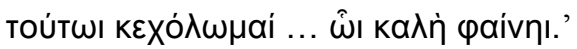

'Don't thank me as if I were making you beautiful;

I'm angry with him to whom you seem beautiful.' (10.11-12)

In literary terms, Aphrodite's response gives the story an unexpected and witty twist of a kind which is common in fables, but it also makes a point about the divine-human relationship. Given that Babrius has just described the slave girl's rituals, Aphrodite's 'Don't thank me' can be read as an instruction about ritual practice as well as the correction of a misunderstanding about what the goddess has or has not done. ${ }^{63}$ Babrius adds the moral (13-14) that those who take pleasure in ugly things as though they are beautiful are cursed by the gods and mentally blind. Aphrodite is therefore also instructing the girl in how to avoid being cursed.

In this story, Aphrodite and the girl both want something, and each wants the other to want what they want. The girl tries to persuade Aphrodite in a conventional way, with prayers and offerings. Aphrodite's response implies that only right understanding will prevent the girl's being cursed, and this is what the god wants. The idea that the gods want to be understood by human beings is prevalent in Aesopic fables too, but the link with cult activity may be particularly characteristic of the early principate. ${ }^{64}$ In a recent paper, I took an observation by Plutarch as a starting point from which to trace through early imperial texts the idea that thinking the wrong things about the gods vitiates one's ritual practice: '[I]t is very well said by philosophers that those who do not learn to understand the names of things correctly misuse the things they refer to as well.' (Mor. 379c) Babrius 10 offers a further hint of a strain of thinking in the early principate that the gods want to be understood by

\footnotetext{
${ }^{63}$ L1. 6-8, though here, as elsewhere, rituals are generically described, including the lighting of lamps, making of sacrifices, and prayers.

${ }^{64}$ Cf. Babr. 63, discussed above.
} 
those who worship them, they want worshippers to want what they have to give them, and if worshippers do not understand and appreciate them properly, not only their thinking, but also their rituals will be compromised.

\section{$3 \quad$ Beyond the Aesopic corpus}

Several fables told by early imperial authors have no surviving Aesopic versions but are interesting in their own right for their portrayal of divine-human relationships. Babrius' Fable 2 is the story of a farmer who loses a fork. He blames his workers (áүроíоı), but they all deny having taken it. He therefore takes them into the local polis to swear to their innocence, 'because,' Babrius says,

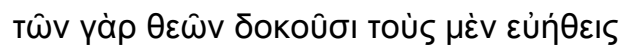

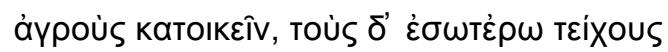

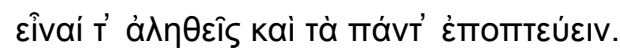

people think that gods who live in the countryside are simple-minded, while those who live within city walls are infallible [or 'reliable'] and see everything.

When the group arrives at the city, however, it hears a herald announcing a reward of 1000 drachmas for information leading to the recovery of property stolen from the temple. Hearing this, the farmer concludes that his journey was pointless: if the god does not know who stole his own property, he is not going to know who stole someone else's. Worse, he is offering money in the hope that some man knows. ${ }^{65}$

The wisdom function of fables encourages readers to take seriously their epimythia or the insights their characters come to at the ends of stories. It is therefore unlikely that the farmer is being presented here as simply wrong in the conclusion he comes to about the god. We are surely supposed to read him as having gained understanding in some way. The point could be that he has misunderstood the relative sophistication of town and country gods, that he has mistaken the proper scope of the

\footnotetext{
${ }^{65}$ Versnel 2011, 399 describes this as an exposé of ambiguous thinking about the knowledgeability of the gods.
} 
gods' activities, or that he has mistaken the relative roles of gods and human beings in the pursuit of justice.

I have not found another example of the idea that urban gods might be regarded as more generally reliable or far-sighted than their rural counterparts. Babrius expresses it, though, in propria persona, suggesting that he really is claiming (not simply saying that the farmer thinks) that some people (not necessarily only country-dwellers) think this way. Human country-dwellers are notoriously less sophisticated than city-dwellers, and are often objects of fun as a result. This fable, though, takes the countryman's perspective. It implies that different groups of people may understand themselves as having the gods they need, or deserve, or that suit them, even if this means that those gods are relatively simple-minded. The first indication of religious mentalité in this fable therefore shows a rural micro-society interpreting its relationship with the divine as appropriate to its everyday situation, but inadequate to a crisis.

What is the connection between the simplicity of rural gods and people and the reliability and far-sightedness of urban gods and people? It is tempting to recall Xenophanes' observations about the relationship between Ethiopians and Thracians and their gods. ${ }^{66}$ For Xenophanes, the likeness of gods to their worshippers implies that conventional cults are social constructions, but Babrius allows a more positive interpretation - or more than one. Those who think that simple gods live in the country and sharp ones in the city could be assuming that the nature of the gods determines the nature of the people who worship them, or that gods choose people to worship them who are like them, or that human beings choose (as opposed to constructing) gods to worship who are like themselves.

The logic of this fable suggests the second alternative, with perhaps elements of the third. The nature of the farmer is not fully determined by his local gods, because he is capable of choosing to consult the gods of the city. We might imagine that he has chosen to worship his local gods most of the time because they suit his situation, but, again, this is not the whole story, since he can also choose to consult an urban divinity. The likeliest implication is that the gods are imagined as choosing communities to worship them who best suit their natures, but that those communities may have needs beyond those of the gods who choose them, so they too exercise

\footnotetext{
${ }^{66}$ Frr. B $15,16$.
} 
choice sometimes, by consulting other gods. In this interpretation, a picture emerges of a religious scene in which human beings' religious activity is framed and creatively constrained by the need to balance piety towards the gods who have chosen them with piety towards those gods who can best help them in particular situations, and in which the choices that result reflect their own complex identities and activities. ${ }^{67}$

On one level (especially to an outsider eye), this is simply a way of saying that divine-human relations map onto intra-human ones. Country people worship country gods, but they also interact with townspeople and therefore sometimes worship urban gods; no doubt they also worship the gods of their state, ruler and so on. From an insider perspective, though, Babrius' vision of divine-human relations is more than a calque of intra-human ones. It implies not just a parallel but a symbiosis, dynamic and at times fluid, between divine and human natures, capacities, and desires. The gods choose their worshippers as well as the other way round, and choose appropriately to themselves. Human beings must choose whether to be defined by the gods who choose them, or to negotiate other relationships as well. In the farmer's actions, there is therefore a hint of the risks inherent in divine-human relations, as well as their benefits.

The idea that a worshipping individual or group, while being in a steady relationship with their local gods, might sometimes want to consult more widely or develop a relationship with a new god, is familiar on a larger scale. The farmer is doing much what states do when, for example, they consult external oracles or introduce a new cult into their pantheon. We usually understand this as a fairly routine and uncontroversial exercise, but Babrius offers a slightly different perspective. His farmer's initial recourse to city gods is presented as a vote of no-confidence (on this occasion) in his rural gods, which (in a witty subversion of expectation of a kind, common in fables, which we have already seen) is itself undermined by his experience in the city. Babrius shows how going over the heads of one's local gods in search of greater authority, far from being a routine form of reassurance, is a provisional and risky exercise, based on hopes of what the gods might be willing and able to do for worshippers which are themselves provisional and imperfectly informed.

\footnotetext{
${ }^{67}$ They also access, as other fables show, major divinities like Zeus and Aphrodite who, even if they have rural cults, cannot have been seen as simple-minded local gods.
} 
On this occasion, the farmer's desire to consult the urban god proves misconceived: the herald makes him realise that the urban god is no more all-seeing than his country cousins. It is hard, within the logic of the narrative, to dispute the farmer's conclusion. If this is part of the conclusion of the fable overall, then it suggests that whatever people think, it is not the case that country gods are less reliable or observant than those of the city. (Alternatively, Babrius could be indicating that city gods are useless, but this would imply more scepticism than his collection exhibits in general about the gods. ${ }^{68}$ ) There is, however, clearly more to the man's conclusion than that. The fable ends with the word anthropon, stressing the fact that the god, as the farmer sees it, is looking for a man to help him find his property. This suggests that the man now realises he has misunderstood the scope of the god's activities: finding lost property is not part of them. With this, the farmer has come to a more sophisticated understanding of his relationship with the gods than he had before.

We should remember, though, that the farmer did not plan simply to ask the god who had his fork. He brought his workers to swear an oath before the god, presumably because he hoped either that fear of the god would make them tell the truth, or that the god would reveal who was lying. The fact that the farmer draws a conclusion about the god from the proclamation he hears, not just about the power of the fear of the god to affect his workers, suggests that he did indeed think that the god would be able to tell him the truth about what happened. Now he realises that the divine-human relationship does not work like that in this kind of case. The god relies on people to secure justice on his behalf. If this is not simply a cynical remark about the impotence of the gods, it points to the conclusion that gods and human beings collaborate in the administration of justice. Elsewhere in the ancient world, including in the early principate, we find a wide range of views about the origin of justice with the gods, the gods' role in executing it, and the relationship between divine and human justice. ${ }^{69}$ In this fable we find an unusual, but perhaps not frivolous contribution to such thinking.

Last but not least, we may note that Babrius never tells us which gods are involved in this fable. Apparently it is not important, suggesting that he thinks what he says is widely applicable to divine-human relations.

\footnotetext{
${ }^{68}$ Morgan 2007, 75-8.

${ }^{69}$ E.g. (of many possible) Segal 1981, Lloyd-Jones 1983, Parker 1997, Versnel 2011, 155-62, 230-3.
} 
The connection between human and divine concepts of justice is also the theme of Phaedrus 4.11. A thief, bent on robbing a temple, lights his lamp at the altar of Jupiter and then robs the god by his own light. As he is leaving, sancta religio speaks to him, saying that even though the gifts he has stolen were offered by wicked men, so the god does not care about them, the thief will be punished for his sacrilege (5-11). Moreover, to ensure that fire dedicated to the gods is not used for crime, hereafter it will be a law that no lamp of any kind can be lit from a sacred flame or vice versa (12-13).

The obvious conclusion, that temple robbery is a sacrilege which one can expect always to be punished, being embedded in the story, Phaedrus offers three further morals (11. 14-21): those we feed may turn on us; crimes are punished by the Fates, and good men should not share with the wicked. Most interesting, however, in some ways, are the story's other embedded assumptions about divine-human relations. As so often, a divinity teaches a mortal something about the gods: they accept gifts from mali despite finding them hateful. This echoes the theme of divine tolerance of human misbehaviour which also appears in the Aesopic corpus, where, for instance, a mortal sometimes dishonours a god without adverse consequences. ${ }^{70}$ It also implies that the gods' view of people and perhaps treatment of them depends on more than people's offerings to them: it depends on their behaviour elsewhere (surely towards other people, since the fact that they have made offerings suggests that their wickedness does not consist particularly in impiety). The gods, that is, operate with a moral code which takes into account more than human behaviour towards themselves. As in other fables, however, there is a point beyond which the gods will not tolerate human misbehaviour, which in this fable is the sacrilegious crime of theft. ${ }^{71}$

Another notable aspect of this fable is that it is Religio, not Jupiter, who speaks to the thief. Free though Romans are with the divinisation of qualities, and although the gods can be thought of as instructing human beings in cult, religio itself is not normally divinised, so the ambiguity of status inherent in such qualities is even more pronounced here than usual. The depiction of a human quality, recognised as divine, passing a new sacred law, highlights the ability of human beings to think and do what the gods want and approve, based on qualities and values which they share.

\footnotetext{
${ }^{70}$ E.g. Aes. 260, Babr. 48, discussed by Morgan 2013, 24-5.

${ }^{71}$ Punishment for sacrilege here is fated rather than decided by Jupiter, suggesting that gods and human beings belong to a system of justice accepted by both: cf. Babr. 117, Versnel 2011, 166-76, 185-7.
} 
These stories offer unexpectedly sophisticated meditations on the nature of divine-human relations in general and on justice in particular. They can be read as implying that gods and mortals share a concept and system of justice, which the gods want mortals to understand and in which gods and mortals co-ordinate, even cooperate to ensure that justice is enacted on the mortal level. This possibility is largely unexplored by commentators on other Greek and Latin authors, who almost always see authors as either representing the gods as defining and administering justice, ${ }^{72}$ or as problematising divine justice. ${ }^{73}$ What may be a more sophisticated relative of the popular idea, however, is extensively discussed by commentators on most of the major philosophical schools. For Platonists, Epicureans and Stoics, in different ways, human virtues derive from the divine, and virtuous human beings live in accordance with divine good. The practice of justice, as a virtue or an aspect of the good, is one expression of right human relations with the divine, and on the human level justice is only possible when wise or virtuous human beings enact it. ${ }^{74}$ To discuss these models in detail is beyond the scope of this study, but when we remember 'high' philosophy's ongoing interest in popular wisdom and acknowledgement of their shared roots, ${ }^{75}$ it may not be too much of a stretch to hear in fables popular forms of ideas which develop into a key part of these schools' metaphysical and political theories. Conversely, it seems possible that popular forms of these theories may have more widespread social currency than philosophers usually assume.

Finally, we turn to a fable which appears first in Plutarch's Consolation to Apollonius $112 \mathrm{a} .{ }^{76}$ When Zeus was giving out prerogatives to the gods, Grief (Penthos) arrived late and the only thing left to give her was what belongs to the dead: tears and sorrow. Just as other gods love those who honour them, Plutarch says, so does Grief. If, therefore, we honour Grief with sorrow and lamentation, she will love us and stay with us, giving us new reasons to grieve. If, however, we refuse to grieve, she will leave us and we will cease to have reasons to grieve.

Grief, here, like love, anger, and other emotions elsewhere in Greek literature, is portrayed as a force which descends on us from beyond ourselves, even as it is on

\footnotetext{
${ }^{72}$ E.g. Lloyd-Jones 1983, Gibson 1999, Scullion 2002, Leigh 2010.

${ }^{73}$ E.g. Poe 1974, Suter 2003, Papadopoulou 2004.

${ }^{74}$ E.g. Annas 1995, ch. 13, Cobb 1989 (on Plato), Schofield 2005, 760-70 (on Stoics), Kechagia 2010 (on Epicureans); cf. Cooper 2004, 247-69.

${ }^{75}$ See e.g. for the early principate Morgan 2007, ch. 11 (arguing that there is more 'trickle up' than 'trickle down' between popular morality and high philosophy in this period).

${ }^{76}$ And at Mor. 609f, where it is attributed it to Aesop.
} 
some level an emotion within ourselves over which we have some control. ${ }^{77}$ Fables not infrequently treat troubling emotions or attitudes, from blindness to one's faults (Babr. 66, Phaedr. 4.10) to insolence (Babr. 87), homoeroticism (Phaedr. 4.16), and deceitfulness (Babr. 57), as divine powers or gifts, capturing our ambiguous relationship with our own psychology: the way we often want to distance ourselves from aspects of ourselves. ${ }^{78}$ It comes as more of a surprise to find Plutarch treating grief in this way; as a philosopher, we might expect him to treat it as an emotion to be controlled rather than as a divinity to be evaded. ${ }^{79}$

The most striking part of Plutarch's story is the idea that we have some control over grief, not as an emotion, but as a divine power. Divine powers, it suggests, can be encouraged or discouraged from taking too close an interest in us. The idea that we encourage the divine to take a positive interest in us by cultivating it is ubiquitous in Greek and Roman thinking. The converse, that we actively discourage a divinity by declining to cultivate it, is less familiar, though we might compare the literary topos that divine qualities such as Fides and Iustitia flee the earth in response to human strife and social turmoil. ${ }^{80}$ By divinising grief, however, Plutarch acknowledges its power, enables us to distance ourselves from it, and ultimately, paradoxically, makes it something we can refuse to engage with. Sometimes, it seems, part of living with the gods means being able to walk away from them.

\section{Conclusion}

Fables of the early principate portray dynamic and colourful relationships between gods and mortals. Their interactions are religious, in the sense that they are typically mediated through prayers, ritual acts, and religious experiences such as dreams, but they are nearly always individual, private, and informal rather than linked to cults, festivals, or other forms of communal religion. Some fables thereby offer a window into aspects of ancient religious thinking which are difficult to access through other surviving sources. Others show divine-human negotiations (for instance, about which god should be approached in a given situation) similar to those we encounter in other

\footnotetext{
${ }^{77}$ Cf. Them., Or. 32, p. 434 (Dindorf) (attributed to Aesop).

${ }^{78}$ Exploring similar ideas in other bodies of literature see especially Padel 1992, ch. 6, Gill 2006, pt. 2.

${ }^{79}$ Cf. Schorn 2009 on Plut., Consolatio ad uxorem.

${ }^{80}$ E.g. Ov., Met. 1.128-50, Petr., Sat. 124, with Piccaluga 1981, 723-32; cf. Babr. 126.
} 
sources, but from an unusual perspective - that of the god or hero him- or herself, or of a sub-elite human agent.

In many ways, divine-human relations in fables of the early principate are well in line with those of the Aesopic corpus, but we have also seen ways in which they are distinctive. In particular, they often depict the gods as rather mild-tempered, as highly moralistic, and as persistently concerned to educate human beings in the symbiotic, even collaborative nature of their relationship. Individual human beings, for their part, negotiate their divine relationships, if often in ignorance, hopefully tactically, and occasionally with remarkable self-confidence.

Most early imperial fables follow their Aesopic models in giving few, if any clues to their setting in political time and place. We might therefore see them as capable of shedding no direct light on the religious practices or mentalité of the early principate. Alternatively, we might see such stories as belonging to the religious longue durée: as expressing ways of thinking about the gods which persisted over centuries, across a wide social spectrum, and which formed a part (one often overlooked) of the religious landscape of the early principate inter alia. If we take seriously the widespread claim of fables to express and teach wisdom, we must, at least, I suggest, take the latter possibility seriously too. By the same token, it is possible that the distinctive aspects of these stories reflect ideas current in their immediate socio-cultural context. If so, we may note that within the complex religious landscape of the early principate there was room for some strikingly positive views of the patience and benignity of the gods and their co-operation with mortals. ${ }^{81}$

The fables discussed here are by no means all those which offer food for thought. In a longer essay one might want to explore, for example, the aetiology of Prometheus/Jupiter and the wallets (Babr. 66, Phaedr. 4.10), the serio-comic story of the herm and the dog (Babr. 48), or the haunting image of the traveller who encounters Truth in the desert (Babr. 126). These examples, however, begin to show how much there is to be elicited from fables about how Greeks and Romans visualised the possibilities of lived diachronic relationships between gods and mortals in the early principate.

\footnotetext{
${ }^{81}$ Elsewhere in literature and in cult we could find both parallels and very different views, but I resist making comparisons here on the basis that fables are worth discussing as evidence of mentalité in their own right.
} 


\section{Bibliography}

Adrados, F. R. 1979-87. Historia de la Fábula Greco-Latina. 3 vols. Madrid:

Editorial de la Universidad Complutense.

Annas, Julia. 1995. The Morality of Happiness. Oxford: Oxford University Press.

Athanassiadi, Polymnia; Frede, Michael (eds.) 1999. Pagan Monotheism in Late Antiquity. Oxford: Oxford University Press.

Barnsley, J. H. 1972. The Social Reality of Ethics: the comparative analysis of moral codes. London: Routledge.

Belayche, Nicole 2010. 'Deus deum ... summorum maximus (Apuleius): ritual expressions of distinction in the divine world in the imperial period'. In Mitchell and van Nuffelen 2010b. 141-66.

Benedict, Ruth 1934. Patterns of Culture. Boston: Houghton Mifflin.

Carnes, Pack (ed.) 1988. Proverbia in fabula: essays on the relationship of the proverb and the fable. Bern: Peter Lang.

Cascajero, Juan 1991. 'Luch de clases e ideología.' Gerión 9. 11-58.

Cerutti, Maria 2010. 'Pagan monotheism? Towards a historical typology.' In Mitchell and Nuffelen 2010b. 15-32.

Chambry, Émile 1927. Ésope Fables. Paris: Belles Lettres.

Chaniotis, Angelos 2010. 'Megatheism: the search for the almighty god and the competition of cults.' In Mitchell and van Nuffelen 2010a. 112-40. 
Cobb, William 1989. 'Plato on the possibility of an irreligious morality', International Journal for the Philosophy of Religion 25. 3-12.

Cooper, John 2004. Knowledge, Nature, and The Good. Princeton: Princeton University Press.

Crusius, Otto 1897. Babrii Fabulae Aesopeae. Lipsiae: in aedibus B. G. Teubneri.

García, C. G. 1978. 'Historia y ética de la fábula esópica', Actas del V Congreso Español de Estudios Clásicos. Madrid: Sociedad Española de Estudios Clásicos. 179208.

Gibson, Roy 1999. 'Aeneas as hospes in Vergil, Aeneid 1 and 4', Classical Quarterly 49. 184-202.

Gill, Christopher 2006. The Structured Self in Hellenistic and Roman Thought. Oxford: Oxford University Press.

Gual, C. G. 1977. 'La fábula esópica: estrutura e ideología de un género popular.' In Estudios ofrecidos a E. A. Llorach, 1. Oviedo: Universidad de Oviedo. 309-22.

Hägg, Tomas 1997. 'A professor and his slave: conventions and values in the Life of Aesop.' In Conventional Values of the Hellenistic Greeks, ed. Per Bilde et al. Aarhus: Aarhus University Press. 177-203.

von Harnack, Adolf. 1924. Marcion: Das Evangelium vom fremden Gott. $2^{\text {nd }}$ edn. Leipzig: J. C. Hinrichs.

Hesseling, D. C. 1893. 'On waxen tablets with fables of Babrius.' Journal of Hellenic Studies 13: 293-314.

Jedrkiewicz, Stefano 1989. Sapere e Paradosso nell' Antichità: Esopo e la favola. Rome: Edizioni dell' Ateneo. 
Karadagli, Triantaphyllia 1981. Fabel und Ainos: Studien zur griechischen Fabel. Königstein: Hain.

Kechagia, Eleni 2010. 'Rethinking a professional rivalry: early Epicureans against the stoa', Classical Quarterly 60. 132-55.

Kurke, Leslie. 2011. Aesopic Conversations. Princeton: Princeton University Press.

Leigh, Matthew 2010. 'Forms of exile and return in the Rudens of Plautus', Classical Quarterly 60. 110-17.

Lloyd-Jones, Hugh 1983. The Justice of Zeus. Rev. ed. Berkeley: University of California Press.

Mikalson, Jon 1983. Athenian Popular Religion. Chapel Hill: University of North Carolina Press.

Mitchell, Stephen; van Nuffelen, Peter (eds.) 2010a. One God: pagan monotheism in the Roman Empire. Cambridge University Press.

Mitchell, Stephen, van Nuffelen, Peter (eds.) 2010b. Monotheism Between Pagans and Christians in Late Antiquity. Leuven: Brill.

Morgan, Teresa 2007. Popular Morality in the Early Roman Empire. Cambridge: Cambridge University Press.

Morgan, Teresa 2013. 'Divine-human relations in the Aesopic corpus', Journal of Ancient History 1. 3-26.

Morgan, Teresa forthcoming. 'Doxa, praxis and Graeco-Roman religious thinking: Plutarch, Moralia 379c.' In Rethinking Christianity in the Second Century, ed. James Carleton-Paget, Simon Gathercole and Judith Lieu. Cambridge: Cambridge University Press. 
Nøjgaard, Morten 1964. La Fable Antique. Copenhagen: A. Busck.

Oltramare, André 1926. Les Origines de la Diatribe Romaine. Geneva: Imprimeries Populaires.

Padel, Ruth 1992. In and Out of the Mind. Princeton: Princeton University Press.

Papadopoulou, Thalia 2004. 'Herakles and Hercules: the hero's ambivalence in Euripides and Seneca', Mnemosyne 57. 257-83.

Parker, Robert 1987. 'Gods cruel and kind: tragic and civic theology.' In Greek Tragedy and the Historian, ed. C. Pelling. Oxford: Oxford University Press. 143-60.

la Penna, Antonio 1961. 'La morale della favola esopica come morale delle classi subalterne nell' antichità.' Società 17: 459-537.

Perry, Ben E. 1952. Aesopica. Urbana, IL: University of Illinois Press.

Perry, Ben E. 1984. Babrius and Phaedrus. Loeb Classical Library. Cambridge, Mass.: Harvard University Press.

Piccaluga, Giulia 1981. 'Fides nella religione di età imperial', Aufstieg und Niedergang der römischen Welt II.17.2. Berlin: Walter de Gruyter. 703-35.

Poe, J. Park. 1974. Heroism and Divine Justice in Sophocles' Philoctetes. Mnem. Suppl. 34. Leiden: Brill.

Postgate, J. P. 1919. 'Phaedrus and Seneca.' Classical Review 33. 19-24.

Schofield, Malcolm 2005. 'Social and political thought.' In The Cambridge History of Hellenistic Philosophy, eds. Keimpe Algra, Jonathan Barnes, Jaap Mansfeld and Malcolm Schofield. Cambridge: Cambridge University Press. 739-70. 
Schorn, Stefan 2009. 'Tears of the bereaved: Plutarch's Consolatio ad uxorem in context.' In Tears in the Graeco-Roman World, ed. Thorsten Fögen. Berlin: Walter de Gruyter. 335-65.

Scullion, Scott 2002. "'Nothing to do with Dionysus": tragedy misconceived as ritual', Classical Quarterly 52. 102-37.

Suter, Ann 2003. 'Lament in Euripides' “Trojan Women”, Mnemosyne 56. 1-28.

Versnel, H. S. 2011. Coping with the Gods. Wayward Readings in Greek Theology. Leiden: Brill.

Veyne, Paul. 1983. Les Grecs Ont-Ils Cru à leurs Mythes? Paris: Editions du Seuil.

West, Martin L. 1984. 'The ascription of fables to Aesop in archaic and classical Greece'. In La Fable: huit exposés suivis de discussions, eds. Francisco R. Adrados and Olivier Reverdin, Geneva: Fondation Hardt. 105-36.

Woolf, Greg 2013. 'Ritual and the individual in Roman religion'. In The Individual in the Religions of the Ancient Mediterranean, ed. Jörg Rüpke. Oxford: Oxford University Press. 136-60.

Zafiropoulos, Christos 2001. Ethics in Aesop's Fables: the "Augustana” collection. Leiden: Brill.

Teresa Morgan

Oriel College, Oxford, OX1 4EW, UK

teresa.morgan@classics.ox.ac.uk 